\title{
Research on the Present Situation of China's International Competitiveness Advantages of Service Trade
}

\author{
Zhi-Juan $\mathrm{ZHOU}^{1, \mathrm{a},{ }^{*}, \text { Feng FENG }}{ }^{2, \mathrm{~b}}$ \\ ${ }^{1}$ School of Management, Guangxi University of Science and Technology, Liuzhou, Guangxi, \\ China \\ ${ }^{2}$ School of Management, Xi'an University of Science and Technology, Xi'an, Shaanxi, China \\ a1574438724@qq.com, ${ }^{b} 544105768 @ q q . c o m$.
}

Keywords: Service trade, International competitiveness advantages, RCA index.

\begin{abstract}
Service trade is the main embodiment of a country's international competitiveness. 2001 to 2014, China's service trade exports and imports rose from 12th and 10th place respectively to 5th and 2nd in the world. But compared with developed countries, there is still a large gap. Therefore, how to improve the international competitiveness of China's service trade has become a major problem. In this paper, by gathering relevant data, calculating China's service trade competitiveness index, international market share, revealed comparative advantage index and industry competition index. And through the analysis of these indicators, identify factors which influence the international competitiveness of service trade, and propose strategies to improve competitiveness.
\end{abstract}

\section{Introduction}

At present, the world economy is in transition to a service-oriented economy, service trade is essential for the development of the world economy, is also the focus of international economic competition in the new period. Developed countries have a high level of competition, in a dominant position in the international service trade, precisely because of their level of industrialization foundation is high and development speed, so they have high level and competitive service. China is a developing country, industrialization level is not very high, and development started late. Now service trade development is just the beginning, comparing to developed countries is relatively backward, but it has a lot of room. Therefore, I hope that through the study of China's service trade international competitiveness, accelerating the development of China's service trade and improving our level of competitiveness, to enhance the level of China's overall economic strength has great practical significance.

Has scholars through analysis on China service trade international market share, RCA index, international competitiveness index, revealed competitive advantage index, found currently China's service trade exist some problems, and proposed countermeasures to upgrade China's service trade international competitiveness[1,2,3]. Some scholars through collect large of data, calculation out China service trade international market share, competitiveness index and so on, analyzing China's service trade international competitiveness[4,5,6]. Also has scholar using Porter of national competition advantage theory, finding factors of effect China service trade export competitiveness, and using econometric model to measure the influence factor's degree[7]. Some scholars analysis the effect factors and metric indexes of service trade international competitiveness, through building return model, empirical analysis these metric indexes have effect on China service trade international competitiveness[8]. Also have other scholars using counteraction analysis, error amendment model, research the factors which effect China's service trade international competitiveness, and have empirical analysis, prove that per capital income, human capital, foreign investment are important factors[9,10].

In summary, this paper on the basis of previous studies, measuring international competitiveness of China's service trade from the international competitiveness and industrial competitiveness, analyzing results to identify factors, and last proposing policies to enhance the international competitiveness of China's service trade. 


\section{Positive Changes in the Development of China's Service Trade}

\section{Total Optimization}

Trade in services imports rose steadily. In 2013, the growth of China's service trade import grew faster than export, and imports amounting to 329.05 billion, increasing 17.5\% more than 2012 .

Services trade deficit continue to widen. In 2013,China's service trade deficit was118.46 billion, increasing 32.1\%.Although in other business services, consultants, computer and information services, architectural services implement 19.55 billion dollar, 16.95 billion dollars, 9.45 billion dollars, 6.77 billion dollars surplus, but in tourism, transportation services, exclusive right to use and license fees, insurance services exist large amounts deficit, inverse difference was 76.92 billion dollars, 56.68 billion dollars, 20.15 billion dollars and 18.1 billion dollars.

In recent years, showed a trend of strong growth of service outsourcing in China and maintain high-speed development. In 2014, the international service outsourcing contract amount 71.83 billion dollars, increasing 15.1\%. Implementation amount 55.92 billion dollars, increasing 23.1\%. By the end of 2014, service outsourcing industry employment 6.072 million people, which universities (including junior college) above 4.047 million, accounting for $66.7 \%$.

\section{Structure Optimization}

Service export structure gradually optimized, high added-value services export growth rapidly. In 2013, China's exports of high value-added services continue to show steady growth, became an important impetus for structural adjustment. Among them, financial services export growth topped up to $54.2 \%$, advisory increasing $21.2 \%$ than the previous year; computer and information services increasing $6.8 \%$, insurance increasing $20 \%$.

Traditional service exports fell slightly. In 2013, the total exports of transportation services, tourism, and construction services were 37.65 billion, 51.66 billion, 10.66 billion dollars, in China's total service exports accounted for $47.5 \%$, drop 5.6\%. Tourism exports ranks first in the services, increasing 3.3\%, in total services exports accounted for $26.3 \%$ down to $24.5 \%$; Transportation services exports came in second fell to $3.2 \%$, from $20.4 \%$ to $17.9 \%$; construction services exports fell $13 \%$, accounts for $5.1 \%$, down $1.3 \%$ over the previous year.

\section{Analysis on International Competitiveness of China's Service Trade}

\section{Analysis on Evaluation Indexes}

\section{Analysis on the Index of Trade Competitiveness}

Table 1. 2000-2014 China's trade competitiveness index

\begin{tabular}{|l|l|l|l|}
\hline Year & Total (billion dollars) & Net import & The index of trade competitiveness \\
\hline 2000 & 660 & -58 & -0.09 \\
\hline 2001 & 719 & -61 & -0.08 \\
\hline 2002 & 855 & -67 & -0.08 \\
\hline 2003 & 1013 & -85 & -0.08 \\
\hline 2004 & 1337 & -95 & -0.07 \\
\hline 2005 & 1571 & -93 & -0.06 \\
\hline 2006 & 1917 & -89 & -0.05 \\
\hline 2007 & 2509 & -76 & -0.03 \\
\hline 2008 & 3045 & -116 & -0.04 \\
\hline 2009 & 2867 & -295 & -0.10 \\
\hline 2010 & 3624 & -220 & -0.06 \\
\hline 2011 & 4191 & -549 & -0.13 \\
\hline 2012 & 4706 & -897 & -0.19 \\
\hline 2013 & 5396 & -1184 & -0.22 \\
\hline 2014 & 6070 & -1600 & -0.26 \\
\hline
\end{tabular}


Scholars called the radio of net exports and its imports and exports volume of the product or industry's as the trade competitiveness index, used to illustrate the product or industry's international competitiveness.

Table 1 shows that 2000-2014 of China's service trade competitiveness index is less than 0 , and the index of the last 4 years are smaller. Thus it can be seen, the international competitiveness of China's service trade has been in a vulnerable position, and have a weaker trend.

\section{Analysis on International Market Share}

International market share is the radio of a country's exports to total exports of world markets. The index is a reflection of a country or region's export products, reflecting a country's overall competitiveness of the export.

Table 2 2000-2014 market share of China's international trade in services

\begin{tabular}{|l|l|l|l|}
\hline \multirow{2}{*}{ Year } & \multicolumn{3}{|l|}{ Export( billion dollars) } \\
\cline { 2 - 4 } & Amount & Growth \% & Proportion in the world \% \\
\hline 2000 & 301 & 15.2 & 2.0 \\
\hline 2001 & 329 & 9.1 & 2.2 \\
\hline 2002 & 394 & 19.7 & 2.5 \\
\hline 2003 & 464 & 17.8 & 2.5 \\
\hline 2004 & 621 & 33.8 & 2.8 \\
\hline 2005 & 739 & 19.1 & 3.0 \\
\hline 2006 & 914 & 23.7 & 3.2 \\
\hline 2007 & 1217 & 33.1 & 3.6 \\
\hline 2008 & 1464 & 20.4 & 3.9 \\
\hline 2009 & 1286 & -12.2 & 3.9 \\
\hline 2010 & 1702 & 32.4 & 4.6 \\
\hline 2011 & 1821 & 7.0 & 4.4 \\
\hline 2012 & 1904 & 4.6 & 4.4 \\
\hline 2013 & 2106 & 10.6 & 4.6 \\
\hline 2014 & 2235 & 7.6 & 4.5 \\
\hline
\end{tabular}

Data can be seen from the above table 2, China's service trade's international market share (the proportion of China's exports) increased from 2\% in 2000 to $4.5 \%$ in 2014, showed that China's trade in services has been showing a growing trend of the market share, though in recent years are floating, but overall has continued to rise. The service trade of our country's share in the international market increased, showed our country's international competitiveness of service trade enhanced.

\section{Analysis on the Competitiveness of China's Service Trade}

\section{Evaluation on Coefficient of Trade Competitiveness in Various Industries}

Trade competition index (TC index), represent a country's import and export trade industry accounted for the difference between the industry's share of total imports and exports, is a powerful tool for analysis international competitiveness of industry structure.

From the above table3 can be seen, the near three years TC index of communication service, building service, computer and information service, advisory, advertising publicity industry are greater than 0 , and overall are in keep smooth and small range rose trend, this show China's service competitiveness advantage in this six big industry compared big, which advisory industry's competitiveness is most strong, second is computer and information service industry. 
Table 3 2011-2013 several larger services TC index

\begin{tabular}{|l|l|l|l|}
\hline & 2011 & 2012 & 2013 \\
\hline transport & -0.107 & -0.098 & -0.105 \\
\hline travel & -0.057 & -0.11 & -0.143 \\
\hline Communication & 0.001 & 0 & 0 \\
\hline Construction & 0.026 & 0.018 & 0.013 \\
\hline Insurance & -0.04 & -0.037 & -0.034 \\
\hline Financial & 0 & 0 & -0.001 \\
\hline Computer and information & 0.02 & 0.023 & 0.018 \\
\hline Exclusive rights to use and special fees & -0.033 & -0.035 & -0.037 \\
\hline Advisory & 0.023 & 0.028 & 0.031 \\
\hline Advertising and publicity & 0.003 & 0.004 & 0.003 \\
\hline Film , video & -0.001 & -0.001 & -0.001 \\
\hline Other business services & 0.033 & 0.019 & 0.036 \\
\hline
\end{tabular}

\section{Analysis on Industry Dominance Index}

Table4 2011--2013 several RCA indexes for service industries

\begin{tabular}{|l|l|l|l|}
\hline & 2011 & 2012 & 2013 \\
\hline transport & 0.994 & 1.009 & 0.919 \\
\hline travel & 1.116 & 1.041 & 0.966 \\
\hline Communication & 0.399 & 0.372 & 0.362 \\
\hline Construction & 3.267 & 2.505 & 2.754 \\
\hline Insurance & 0.756 & 0.767 & 0.743 \\
\hline Financial & 0.066 & 0.144 & 0.138 \\
\hline Computer and information & 1.208 & 1.272 & 1.251 \\
\hline
\end{tabular}

From the above table4 we know that, in recent years, China's transportation, tourism, construction, computer and information services have made great achievements, relatively strong international competitiveness, particularly in construction services, international competitiveness is strong. Therefore, China should pay more attention to these developments, but also pay attention to other weaknesses to strengthen, in order to improve all-round international competitiveness China's service trade.

\section{Factors Which Influence International Competitiveness of China Service Trade}

\section{Scientific and Technological Strength}

Since China entry into WTO, market opening, service opening is one part of it. The opening services market promoting service technical exchange between China and other countries, drawing on the successful experiences from other countries. In addition, you can also raise the level of China's service industry development, facilitating the export of products of China's service industry. However, due to China's scientific and technological strength is weak, trade in services innovation is not obvious, the introduction of digestion and absorption capacity is limited, so that scientific and technological strength is also an important factor which influencing international competitiveness of service trade in China.

\section{Labor Quality}

"Service" is important characteristics of service sector, which determines the service product from the production, processing, trading and so on series of processes inseparable from human 
resources, whom the quality level of human resources played a key role in the service industry deal. As service workers, their working attitude, professional skills, familiarity with the products and services all affected customer satisfaction with the product, which must impact on the trade in services, which are inextricably linked with the worker's quality level.

\section{Trade in Services Export Structure}

The above analysis show that, strong competitiveness of China's service trade industries mainly in transport, tourism, construction services, computer and information services industries, because of their superior resources, belonging to the labor-intensive industries. However, communication services, insurance services, financial services weak competitiveness of such modern service industry. Although China is accelerating the development of modern service industry in recent years, the effect is not obvious; level of competitiveness compare with developed countries is still a large gap. Reasonable service export structure to enhance the international competitiveness of China's service trade plays a crucial role.

\section{Summary}

To sum up, service trade has become the most rapidly developing areas in international trade. In the present situation, under the trend of economic globalization and liberalization of service trade, China constantly improving service trade of our country's international status, in order to our country into line with the world service trade. Thus, the international competitiveness of service trade has special importance for service trade development in China.

Based on the index of competitiveness of China's service trade、 international market share revealed comparative advantage index , index of competition in the industry, by analyzing the present situation of China's service trade international competitiveness and influence factors, know that scientific and technological strength、 labor quality、service trade export structure are important factors which affecting international competitiveness of service trade. So China should solve the problem of service trade, and propose some solutions: upgrading emphasis、 promoting the service sector and strength improving labor quality、optimizing trade structure improving the management system. When we solve the problems of service trade, we should draw on the successful experience of developing countries on service trade, to improve the shortcomings in the process of the development of service trade in China. We believe that China still has a bigger space for the development of service trade.

\section{References}

[1] Yan Wang, He Gao. Study on the international competitive power of China's foreign service trade [J].Journal of Changchun University of technology (Social Sciences Edition),2011, pp.46-48.

[2] Chenggang Wang. Research on the China's service trade-- in the perspective of international competitiveness [J].Foreign Trade,Dec.2011, 22-24.

[3] Qing Wang. The study of China's service trade international competitiveness and influence factors[J].Northern Economy,Jun.2013, pp.8-12.

[4] Xiuqing Wang, Hang Guiying. Analysis on the international competitiveness of China's service trade and strategies to improve [J].Commercial Times, 2012, pp.42-43.

[5] Yanfang Zhang, Hui Zhang. Ramsey-based inspection of international competitiveness of China's service trade [J].Economic empirical, Nov.2014, pp.141-143.

[6] Huiming Zhuang, Ting Bao. The Study on competitiveness of China's service trade based on services trade openness [J].East China Economic Management, Jan.2014, pp.51-54. 
[7] Xiaofen Chen. Factors affecting the competitiveness of China's service trade--Based on the regression and co-integration analysis [J].Foreign economy and trade, Nov.2012, pp.38-40.

[8] Ping Kong. Analysis on international competitiveness index of China's service trade [J].Journal of Hubei University of Science and technology, 2015, pp.40-42.

[9] Weisi Dai. Analysis of present situation, problems and countermeasures of the development of China's service trade[J].Journal of Jilin Agricultural Science and Technology University, Mar.2015, pp.39-42.

[10] Jinpeng Jiao. Study on the factors which affecting the competitiveness of China's service trade [J ] Journal of Harbin University of Commerce, 2013, pp.26-33. 